\title{
Furry Boarders
}

By WILMA R. AIM, Age 13

Grade 9, Bredenbury High School

If you were to visit our farm, you would find it on the bank of a marshy creek. It is not unusual then, in such surroundings, that we have grown up in close communion with nature, and made friends with many species of wildlife. I have often seen the muskrat, furry little fellow, whisking along a quiet path or shyly poking his nose above the water. But it was not until two years ago that I had an opportunity to observe his customs and habits closely.

It all began in the late fall, just after the first snowfall. Tracks appeared, first around the house, then the barn. Then, one morning when dad opened the barn door, on his way to morning chores, he found a small muskrat curled up in one of the stalls.

Johnny, for that is what we called the little fellow, quickly made himself at home and built himself a comfortable nest of hay. We had several cats at the time, all of which slept curled together in a heap in the hay. When the weather became colder, Johnny joined them, and there we would find him curled up, fast asleep. We were afraid at first that some of the older

\section{Paddy Boy of Ardagh}

When the snow clears away and the frost is out of the ground we shall plant a small Fast-growing Pine.

He might have-he should havelived out his days in peace and safety. But he died - a victim of a way of life, where Society tolerates Power, and the weak and gentle have no place. cats would harm the muskrat, but they never bothered him. The kittens welcomed a new playmate and would roll over and over on the floor in play with him. Johnny ate with the cats at their dish and he loved to nibble at the pail in which their food was carried.

In an empty stall we placed a large tub and kept it filled with fresh water. This the little fellow loved and would wash himself several times a day, using both paws in a manner similar to that of a cat. Every inch of his body was scrubbed, even the long rat-like tail. Then, finished, he would hop from the tub and wring the water from the fur.

When winter was almost over Johnny was joined by his wife, or husband, as the case may be. She appeared in the same mysterious manner as Johnny had and immediately took up housekeeping. She never became quite as tame as Johnny, he liked to have his back scratched with a short stick; this she wouldn't allow. We never attempted to handle the two, though they were so tame that I believe it would have been possible. They both were adventuresome and Johnny often attempted to nibble at our rubbers (this I tried to discourage as I never knew how large a nibble he would take).

The couple began to build a new nest and they became more distant in their attitude. Presently the young were born. We could hear their tiny cries but never saw them. The older ones seldom ventured from their quarters and distinctly longed for privacy, for they began the hopeless (Continued on page 17) 


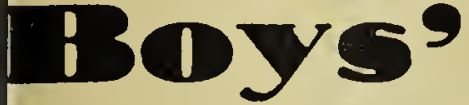

do: Write an original observations. Confine Send your name, ad$\mathrm{bl}$ to the editor, L. T. t., Regina.

Field Guides (birds, or Wherry's "Flower $n$ to the "Blue Jay" or the best story retheir discretion the al additional prizes. please indicate your for the reception of will be October 15 .

\section{Gîr's Secthon}

Prize Winners - The essays submitted for this issue were judged by Mrs. Mary Houston and Mr. Cliff Shaw, both of Yorkton. The results are as follows:

1st Prize - "Furry Boarders," by Wilma Aim, donated by Mr. Cliff Shaw.

2nd Prize - "A Few Wild Flowers," by Elizabeth Hubbard, Grenfell, donated by Miss Margaret Belcher, Dilke.

3rd Prize - "An Evening's Experience," by Anne Matthews, Nipawin, donated by Mrs. Stuart Houston, Yorkton.

\section{Yellow Rails}

RONALD HOOPER, Somme, Sask.

On June the first my brother and I went to a large marsh, at the confluence of the Bowman and Shand Creeks, seven miles north of Weeks. The water was up to three feet deep, and there was a heavy cover of dry sedges. Here we found an abundance of Wilson's Phalaropes, Short-billed Marsh Wrens, Soras, Bitterns, Bobolinks and Wilson's Snipe - but, most interesting of all, we heard a strange ticking noise: "Tick-tick, Tick-ticktick, tick-tick, tick-tick-tick, ticktick, tick-tick-tick" in syllables of twos and threes. The notes of the three syllables were uttered more rapidly than those of the two. It was of the same tone you would get by tapping two stones together. We wondered if it could be the Yellow Rail. Search as we did we could not catch sight of the strange ticker.

On June the eigthth, we returned to the marsh. I heard the ticking quite near me, so I went to a thick clump of dry sedges and felt around in it, when behold! - a yellowish bird with black markings and white wing- bars flew out from under my hand. It flew with rapid beats of its short wings, rather fast for a rail.

It is interesting that God has made creatures that man is seldom able to see, even though $\mathrm{He}$ is the head of created things. At least Yellow Rails will not come to the fate of the Whooping Crane by being shot by man. We must take care that we do not seriously effect the abundance of such water birds by the draining of our marshes.

\section{Furry Boarders}

\section{(Continued from page 15)}

task of packing the large door of the barn shut with straw and hay. This they would carry in their mouths and pack it firmly with their paws. As soon as the door was opened the packing would fall away, but this did not daunt them and they would begin again.

On the first warm spring day, the family left as quietly as it had come. We looked for them back this winter, but they did not appear; apparently they have forgotten us. At any rate, we haven't forgotten them. 